\title{
How Technology and Innovation Drive Two Emerging Giants: China and India?
}

\author{
DOUGLAS ZHIHUA ZENG ${ }^{*}$
}

Being the two most populous, and rapidly catching up developing countries, China and India's emergence is briskly changing the global growth dynamism and economic structure, and has been receiving great global attention all over the world. This paper is intended to examine these two countries' successes from a knowledge and innovation perspective, and to highlight some policy measures for ensuring longterm success. According to the author, the success of these two countries can be mainly attributed to: 1) successful economic reforms backed with clear visions and strategies from the top leadership in the face of crises; 2) tapping into the global knowledge and technologies through FDI foreign direct investment (mainly China) or Diaspora (especially India); 3) the creation of critical mass of innovation and human capital capabilities through a large pool of scientists and engineers and skilled labors; and 4) catching newly emerging knowledge-intensive industries such as information and communications technology (ICTs) and software. To maintain the current dynamisms and ensure continued success, both China and India need to take some effective measures to strengthen their long-term institutional, innovative, and human capacities. These mainly include improving the governance and the overall investment climate; spurring science and technology $(\mathrm{S} \& \mathrm{~T})$ and innovation activities, especially those of the private sector, and strengthening technology diffusion; enhancing R\&D efficiency through better linkage with the production sector; further tapping into the global knowledge and technology stock; further leveraging the innovation clusters; improving the quality of education, especially that of the higher education, and establishing a lifelong learning system through a solid accreditation, certification, and qualification system, and extensive use of modern technologies.

Keywords: China, India, technology innovation, economic growth, knowledge, competitiveness

\footnotetext{
* The author is an Economist at the World Bank, Washington, D.C.; E-mail: Zzeng@worldbank.org He participated in the research and writing of the following World Bank reports: Korea and the Knowledge-based Economy - Making the Transition (2000); China and the Knowledge Economy: Seizing the 21st Century (2001), and Chile New Economy Study (2003), and many others. The findings, interpretations, and conclusions expressed in this paper are entirely those of the authors. They do not necessarily represent the view of the World Bank, its Executive Directors, or the countries they represent.
} 


\section{INTRODUCTION}

7 his paper will focus on the two most populous and rapidly catching up 1 developing countries - China and India (Figure 1 illustrates strong GDP growth performance) from a knowledge and innovation perspective. Due to their sheer size - one-third of world population and 18.5\% (in PPP term) of world GDP altogether - which are important for S\&T capacity and innovation, abundance of labor, and market, they are worth being singled out to be examined in detail, especially in a comparative perspective.

\section{Figure 1. ChINA AND INDIA'S KNOWLEDGE ECONOMY SCORECARDS}

China, India(most recent)

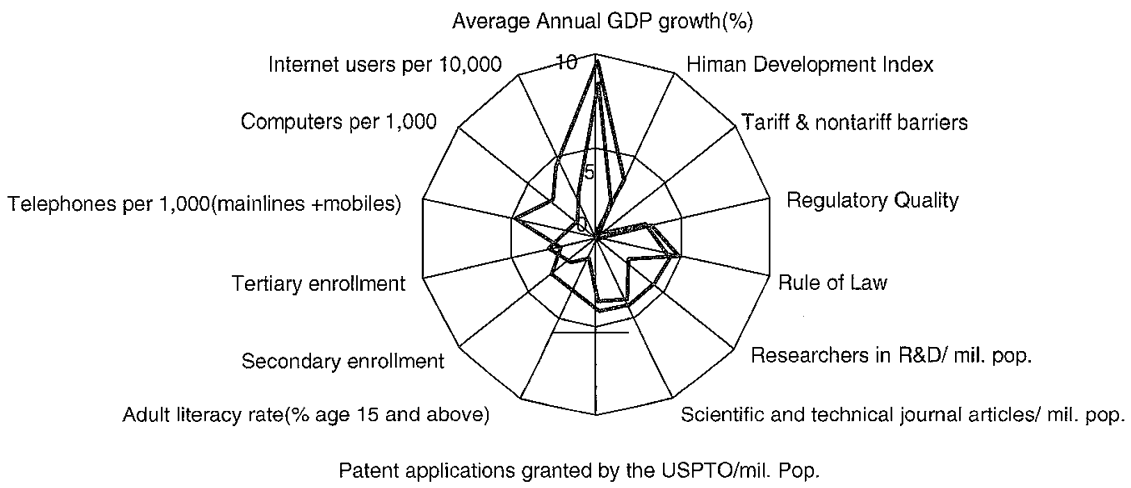

SOURCE: WBI K4D Program

The success of these two countries can be mainly attributed to several factors. These include: 1) successful economic reforms backed with clear visions and strategies from the top leadership in the face of crises; 2) tapping into global knowledge and technologies through FDI (mainly China) or Diaspora (especially India); 3) the creation of a critical mass of innovation and human capital capabilities through a large pool of scientists and engineers and skilled labor; and 4) catching newly emerging knowledge-intensive industries such as ICTs and software.

The paper will first examine the crises that triggered China and India's reforms. The next section will discuss knowledge initiatives, which marked the transition towards a knowledge economy and the implementation of the knowledge strategies. This will be followed by examining key success factors, such as tapping into the global knowledge stock by FDI or Diasporas, dynamic innovation systems, especially the pockets of vitality and competitive niches, and massive relatively skilled human infrastructure. Major challenges for the future will be discussed, followed by strategies for continuing success. 


\section{CRISES FOR CHANGE}

In China, Mao and Hua's policy failures had left China in a state where "agriculture was stagnant, industrial production was low, and the people's living standards had not increased in twenty years" (Nathan 1990). The traumatic experience of the Cultural Revolution had eroded popular trust in the moral and political virtue of the Chinese Communist Party (CCP). The party's leaders decided to shift the base of party legitimacy from virtue to competence. To do this, they had to demonstrate that they could deliver the goods. Reform was desperately needed to save the country and the party itself.

In India, a severe balance of payments crisis occurred in 1991, due mainly to fiscal laxity, growing reliance on external borrowing, a weakening financial sector, and heavy-handed regulation of trade and industry. The proximate trigger was the Gulf War in the second half of 1990-91, which jacked up international oil prices (and India's oil import bill) and reduced remittance inflows from the Gulf. The increase in doubts about India's ability to manage current account pressures triggered adverse effects in capital accounts, which compounded the external sector problem. By March 1991, the current account deficit in the balance of payments had reached a record level of nearly US $\$ 10$ billion, or over 3\% of GDP. The short term external debt to foreign currency reserves was $380 \%$. This situation called for serious reform. One thing worth noting is that although India's new development strategy did not start until the 1991 crisis, it has been preparing skillful human resources long before the crisis, including a large pool of scientists, engineers, and technicians, laying the important foundation for its knowledge revolution. This process may be an unplanned one, but certainly hits the right path.

\section{KNOWLEDGE INITIATIVES AND IMPLEMENTATIONS}

\section{China}

In China, Deng Xiaoping carried out a series of policy and economic reforms initiated in 1978, notably:

- Property rights change starting in rural areas - household responsibility system of farms;

- Pursing the open-door policy, and setting up special development zones targeting FDI and high and new technologies beginning in the coastal areas;

- Encouraging trade and export-led growth;

- Promoting township and village enterprises; and

- Restoring the education system, especially higher education.

The policy of openness (allowing imports of capital flows, technologies, and 
management competencies) along with other major policy reforms greatly enhanced China's market competitiveness and efficiencies, triggering China's extraordinary takeoff (official statistics show that real GDP grew at an average $9.4 \%$ per year in 1979-2002). A World Bank study estimates that nearly a quarter to a third of China's post-1979 growth is from increases in organizational and production efficiency as a result from the reforms. Other estimates of the sources of growth suggest that technological advances sped up in the 1990s with the opening of the economy and inflow of FDI, raising the demand for skilled labor. Technological growth has averaged above $2 \%$ per year, strong performance by international standards (World Bank 2003).

The strong growth of 1979-84 was mainly a result of the shift of labor from agricultural to non-agricultural industries. The introduction of the household responsibility system, rising agricultural procurement prices, and freedom to sell output in excess of government quotas at market prices improved rural-urban terms of trade by more than $40 \%$. Rising farm incomes allowed higher savings to finance new rural enterprises. While the share of agriculture in total employment fell from 62 to $53 \%$ between 1978 and 1985, the share of township and village enterprises rose from 7 to $14 \%$. During 1985-92, growth mainly benefited from the improved efficiency of resource allocation. At an early stage in reform, with prices of industrial goods gradually liberalized and with market transactions steadily expanding in the economy, the Chinese economy opened up to foreign trade and investment. The gradual process of liberalization encompassed expanding the number of enterprises allowed to participate in foreign trade, replacing trade procurement targets by market-based trade policy instruments such as tariffs, quotas, and duty exemption schemes, gradually reducing trade barriers, and finally, increasingly the use of market mechanisms in foreign exchange allocation and moving from a dual to a unified exchange rate system in 1994. Greater uses of markets for resource allocation and opening to foreign trade have contributed to improving the efficiency of resource allocation and led to higher productivity growth. As the economy further opened in the early 1990s, technological progress and labor productivity growth accelerated (see Figure 2).

Figure 2. China's Labor Productivity between 1987 AND 1997 (YUAN PER Person)
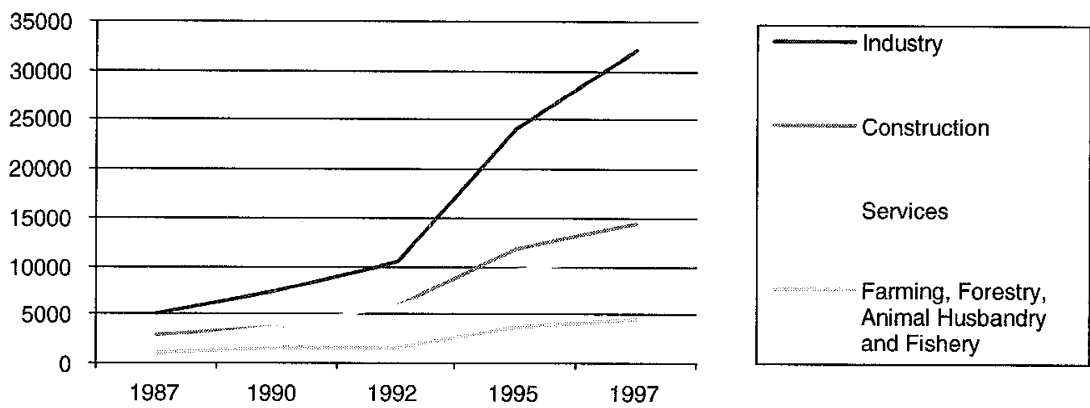

SOURCE: Hwa 2000 and World Bank staff calculations 
Annual gross FDI inflow jumped to 6\% of GDP by 1994 . Imports of capital equipment by foreign invested enterprises in 1987-95 exceeded those of domestic firms by more than two and half times. Such imports are an important source of embodied technological progress, and exemplify the role of foreign invested enterprises as a major locus for the inflow of new technologies, scientific knowledge, and modern management practices (World Bank 2003). The role of FDI in China's technological progress and economic development is crucial (detailed below). China's entry into the WTO in late 2001 further facilitated its transition towards a marketbased economy, boosting the roles of FDI and foreign trade.

\section{(1) FDI: A Key Driver of China's Economic Development}

One of the most important elements of China's open-door policies is the promotion of foreign investment and trade, initiated in 1979. China has taken a gradual reform approach in all FDI-related policies. This is shown by the gradual shifts from the establishment of the four Special Economic Zones (SEZs) to the nationwide implementation of open policies for FDI; from granting permission for joint ventures to allowing wholly foreign-owned enterprises; from tight foreign exchange control to RMB convertibility on current account; and from offering tax incentives to granting national treatment (Chen 1997). Specific incentives include a corporate tax rate of $15 \%$ for three years, after a two-year tax holiday once they have recorded a profit, compared to a standard $33 \%$ rate for domestic firms, as well as duty-free concessions for imported equipment, improved land use rights, and other advantages.

These policy incentives led to very fruitful results. By 1999, China was third in total FDI stock globally, trailing only the United Kingdom and the United States, and was home to more than a third of the foreign affiliates of multinational corporations. By 2004, China's total FDI stock reached US $\$ 562.1$ billion.

The technologies that corporations brought to China have already accelerated China's modernization. The contributions are obvious in everyday activities, in the high-technology practices in newly established Chinese firms, and even in some more traditional enterprises. Foreign enterprises were also responsible for some $48 \%$ of exports in 2001 (less than 9\% in 1989). More than $90 \%$ of exports by foreign enterprises were manufactured goods, in which machinery and equipment and "other" manufacturing were prominent, helping China win the title of "world factory." China's share in global total manufactured exports increased from less than $2 \%$ in 1985 to $6 \%$ in 2000 . In technology-intensive industries, FDI's share of exports rose from 59\% in 1996 to $81 \%$ in 2000 (UNCTAD 2002). There is some evidence to suggest the deepening of local content and the occurrence of industrial upgrading. Local component suppliers in China are growing in number, density, and capability. This is particularly so along the coastal regions, such as in the case of Volkswagen (Box 1). FDI's role was even more important in the early years of developing technology parks, as foreign firms formed the nuclei 
of these important building blocks of the Chinese high-tech industry.

\title{
Box 1. Foreign InVestment Generating Domestic Industry
}

\begin{abstract}
Volkswagen's Shanghai plant has increased production more than 100-foldfrom assembling 2,000 cars in 1985 to 230,000 in 1999 . Revenues rose from 60 million yuan in 1985 to 26.6 billion in 1999. Labor productivity - the value of sales per person - increased from 40,000 yuan in 1985 to 3 million yuan in 1999.

Besides producing cars for the Chinese market, the plant has developed an extensive domestic supplier network to increase its local content. Its first model, the Santana, went into production in 1985 with $2.7 \%$ local content. By 1999 local content was $93 \%$ of value. For its second model, the Santana 2000, local content increased from $70 \%$ in 1995 to $88 \%$ in 1999.

When the Passat 2000 (technically identical to the German version) entered production in 2000, local content was $53 \%$ because of the more demanding specifications. With competition likely to increase once China joins the World Trade Organization, Volkswagen is strengthening the training of its Chinese suppliers to enhance their quality and competitiveness. It is promising domestic parts suppliers able to meet its price and quality standards that they will become part of its global supplier network.
\end{abstract}

SOURCE: World Bank staff visit to Shanghai Volkswagen plant, June 2000

\section{(2) Promoting High-tech and Exports through High-tech Parks and Economic and Technology Development Zones}

To attract FDI and encourage high-tech firms to build China's high-tech industry, China set up a number of high-tech parks or special development zones as pilots since the 1980s. Special policies, such as preferential tax policies, were adopted to facilitate foreign investment. These policies include discounted land price, tax refunds on exports, import duty exemption and concessionary value added tax (VAT), and the like. Initially, there were many high-tech parks, but some were not up to par. After some reassessment, only fifty-three technology parks were officially registered and supported by the government. In 1999, the fifty-three technology parks accounted for about $10 \%$ of industrial production. A large part of their activities, about $45 \%$ of their total output, was in electronic products and telecommunication equipment. They were responsible for producing more than $55 \%$ of the whole country's computer-related products. Foreign enterprises of non-Chinese origin were responsible for more than $62 \%$ of the parks' exports (Hong Kong, Macao, and Taiwan, those of Chinese origin add another 14\%).

The parks included 17,498 enterprises, employing 2,210,487 people by the end of 1999. The ten largest parks employed more than one million persons, showing a relatively strong concentration of activity: Thirty-six of the fifty-three parks had more than one-hundred enterprises. The growth of technology parks has been more than $25 \%$ a year on average. The contribution of such high technology parks to employment, output, and exports will continue to grow (Dahlman and 


\section{Aubert 2001).}

The first and most important high-tech park in China is the Zhongguancun high-tech zone in Beijing, launched in 1988. It is known as China's "Silicon Valley," featuring more than 500 R\&D centers (over forty of which were set up by multinational corporations), regional headquarters, manufacturing bases or joint ventures for multinational giants such as IBM, Nokia, Motorola, Microsoft, Intel, GE, Kodak, Siemens, and Samsung (Angresano 2002). There are over 6,000 enterprises employing more than 246,000 persons, focusing on information and biotechnology. Over half of China's top 200 internet companies are based in this park. The park's economy has been growing at an average rate of $30 \%$ a year since its inauguration. In 2000 , technological, trade, and industrial revenue in this park totaled US\$14 billion, contributing to $60 \%$ of Beijing's industrial growth that year (Zhongguancun Technology Park website). Following its success, many more zones were set up: Shanghai, with 400 enterprises and 100,000 employees, and Shenzhen, with 100 enterprises and 40,000 employees, are among the largest. Another very successful high-tech park is the Suzhou Technology Park in Jiangsu Province (Box 2).

\section{Box 2. Suzhou TeChNOLOgY PARK}

Suzbou New and High-technology Innovation Service Center, Suzhou International Business Incubator, and China Suzbou Pioneering Park for Overseas Chinese Scbolars (the three functions are basically carried out by the same staff; hereafter they will be referred as "park") is a nonprofit technological service institution. In 1994, the first incubation site was put into use. In 1996, the United Nations Development Programme and the Ministry of Science and Technology approved it as one of the first four international business incubators in China. In 1998, the Ministry of Science and Technology, the Ministry of Education, and others jointly set up China Suzhou Pioneering Park for Overseas Chinese Scholars.

By 2000, 300 enterprises are located in the park, out of which 90 were set up by overseas Chinese and 10 were set up by $\mathrm{R} \& \mathrm{D}$ institutes and universities. Forty-six enterprises are high technology enterprises, accounting for 20 percent of all enterprises in the park. About 450 projects have been conducted in the park, and 60 of them are national-level key projects. By the middle of 2000, the park has yielded an output of 6 billion yuan, employed about 3,000 people, out of whom around 400 are employed by overseas Chinese firms, 100 have Ph.D.s, and about 200 are overseas Chinese. The park has attracted many high-quality overseas Chinese with active information campaigns (visits abroad, web communications, etc), and use of central ministries programs.

Key factors for the success of the park include the following:

- Investment. The Suzhou government set up a venture capital of 100 million yuan to provide seed money; meanwhile, the park attracted overseas venture capital to invest in the park. In addition, banks and financial organizations, such as the China Trust and Investment Company, the Chinese Commercial and Industrial Bank, and the Transportation Bank, also provided loans to small private firms with more dynamism and flexibility.

- Infrastructure building. The park built an incubation site of 38,000 square meters with Internet connections every 10 square meters, conference rooms, a multimedia room, a technical trading room, information centers, product testing centers, public labs, and so on. In addition, the park also provides resources such as an accounting office, law firm, business planning space, and other services for all the enterprises, reducing the burdens on start-ups. 
- Import-export service. The park provides free import-export services, including customs declaration, bounded warehouse, and so on.

- Human resources support. The park has a labor market, which holds three big recruiting events each month and has a human resource database. In addition, some recruiting firms also help to identify qualified people.

- Management consulting services. University professors and successful entrepreneurs give management and business training, including seminars and case studies. To promote products, the park set up networks to help relevant enterprises introduce their products, organizes public media visit, hosts exhibitions. Most importantly, enterprises gain membership in the Shanghai Technology Stock Exchange, thus obtaining investment, projects, new products, and market related information.

SOURCE: Author's account based on a field visit in 2000

Propelled by its technology park and special development zone, the Suzhou municipality emerged as a rising star in attracting FDI. It became known for a market-friendly local government that supported technology transfer through contract-based production of parts and components for Shanghai's enterprises.

Beyond the high-tech parks, China also set up economic and technology development zones or special economic zones (SEZs), which mainly target export-oriented manufacturing transnational corporations (TNCs), particularly in high-technology industries. China now has forty-nine national zones, complemented by literally hundreds of export processing zones, development zones, industrial parks, and science and technology zones at the sub-national levels. They are established to attract not only foreign investors but also domestic companies (UNCTAD 2002). Since 1985 , over $85 \%$ of FDI into China has gone into SEZs (many high-tech parks are located within the SEZs), which are located in eleven provinces and provincial-level municipalities along the eastern coast, particularly in Southern China's Hainan and Guangdong provinces, as well as to the greater Shanghai and Beijing areas (The Economist Intelligence Unit 2002). The Shanghai area has been receiving over US $\$ 3$ billion in FDI annually since 1997, with about one-third going to the Pudong SEZ. This SEZ, which twenty years ago was a rice paddy, has attracted almost US $\$ 40$ billion FDI since 1990. Firms established from FDI are so important to Shanghai that they now account for about 30\% of its GDP, $50 \%$ of its fiscal revenue, and over $75 \%$ of its high technology output (China Daily 2002).

These measures have been very effective in attracting high-tech FDI. By 2002, high-tech TNCs have set up over one-hundred R\&D centers, mostly in the Shanghai and Beijing areas. For example, Motorola established eighteen R\&D centers in the areas of electronics, with Microsoft establishing three. These R\&D centers have played a significant role in enhancing the innovative capacity of foreign affiliates and upgrading their activities.

\section{(3) Tapping Into the Overseas Diaspora}

In addition to the market potential, low labor costs, and labor productivity 
attracting FDI, one important feature of China's FDI is the contributions from the overseas Chinese Diaspora. From the early nineteenth century until 1949, there was considerable migration, mostly from coastal provinces to neighboring countries or regions. Since the open-door policy, more Chinese go abroad to study or work. An estimate of Chinese Diaspora by 2001 was 55 million (Huang and Khanna 2003). Many of these overseas Chinese became successful entrepreneurs or part of the wealthy class, and wished to invest in the homeland. The economic reforms since 1978 provided great opportunities for them. The government sought to appeal to the overseas Chinese for both capital and technology as part of the country's new development campaign. Since China was in the early stages of development, it offered overseas Chinese investors considerable profit opportunities in emerging industries. The familiarity with Chinese culture, language, and business mentality combined with a stable political environment, preferential policies, and promises of reform induced many overseas Chinese to invest in small- and medium-sized ventures. Investment by overseas Chinese not only accounts for the lion's share of total foreign investment in China (as high as 60-80\% from 1983-1996, see Table 1), but also has a herd effect in inducing other investors to follow.

\section{Table 1. Overseas Chinese Investment and Share in China's Total Foreign} INVESTMENT

\begin{tabular}{c|c|c}
\hline Year & Investment (million US\$) & Share $(\%)$ \\
\hline 1983 & 525 & 83 \\
1984 & 790 & 63 \\
1985 & 1079 & 65 \\
1986 & 1390 & 74 \\
1987 & 1962 & 85 \\
1988 & 2637 & 83 \\
1989 & 2758 & 81 \\
1990 & 2517 & 72 \\
1991 & 3393 & 78 \\
1992 & 8291 & 75 \\
1993 & 22177 & 81 \\
1994 & 24415 & 72 \\
1995 & 26127 & 70 \\
1996 & 28124 & 67 \\
\hline
\end{tabular}

SOURCES: China State Statistical Bureau (1979-1991, 1994, 1996), Zhang (2000)

\section{(4) Upgrading Traditional Industries with New Technology}

In addition to high technologies, China also successfully upgraded some traditional industries with new technology, such as rice production and some manufacturing 


\section{industries.}

A distinguished example is China's hybrid rice, invented by Longping Yuan, a famous agronomist. Beginning hybrid rice research in 1964, Yuan, an academician of the Chinese Academy of Engineering, used genetic technologies to develop three strains of hybrid rice (male sterile, maintainer, and restorer) and obtained the world's first high-yielding hybrid rice strains in cooperation with other scientists in 1973. He made a breakthrough in hybrid rice breeding and perfected production techniques in 1984. Since its development, hybrid rice has been introduced to more than half of the rice acreage in China, makes up over $60 \%$ of its total rice output, resulting in a $20 \%$ higher yield over previously grown varieties. That $20 \%$ increase translates into enough food to feed an additional 60 million people per year in China. As a result, several million hectares of paddies have been released for growing other crops to raise farmers' incomes. Due to Yuan's accomplishments, including helping to establish the hybrid rice seed production industry in China, Yuan received the 2004 World Food Prize (Law 2004). To spread technology to other developing countries, China has sent veteran rice specialists to Bangladesh, India, Indonesia, Myanmar, Vietnam, and other south and southeast Asian nations to impart hybrid rice nursing, cultivating, and other related technologies since the early 1990s (People's Daily 2004).

China also made great progress in manufacturing sectors by using new technologies in metallurgy, textiles, and automobiles. The development and application of key technologies and facilities for high performance continuous casting raised the continuous casting ratio of the metallurgical industry from $47 \%$ to $82 \%$, improving the production efficiency of enterprises by $40 \%$ (Ministry of Science \& Technology of China 2004). Built on its local strengths of $R \& D$ and labor, combined with foreign technology, China is expected to export cars to the US and Europe as soon as 2008 (Bradsher 2005).

\section{(5) Building a Skillful Labor Force and Large Pool of Talent}

China's success largely hinges on its big and relatively skillful human capital base and a critical mass of talented scientists and engineers, which form the backbone of its innovation system. Due to China's Confucian tradition of emphasizing education and the government's continued efforts, China has greatly improved the educational levels of the whole population, though still low compared to developed countries and characterized by large regional disparities.

China's educational reform and training system began in 1979, gathering pace in the 1990s. Major changes include a process of decentralization, the introduction of fees for non-compulsory education, the growth of independently funded educational institutions, and reform of the curricula to meet the changing needs of the emerging market economy. The Ninth Five-Year Plan (1996-2000) identified education as a priority for the next stage of China's development, specifically targeted the following 
areas:

- Basic education (primary and secondary) for poor areas. Yuan 10 billion (US\$1.2 billion) was to be invested in twenty-one provinces over the next five years:

- Vocational education (including distance education). Priority to be given to training for finance, taxation, banking, industry, and commerce;

- High level training to be provided by universities to increase the output of those skilled in science and technology, business administration, human resource management, economics, finance, and law.

TABLE 2. BASIC TECHNOLOGY AND INNOVATION INDICATORS (2001-02)

\begin{tabular}{l|c|c|c|c|c|c}
\hline & China & India & USA & Japan & Germany & Russia \\
\hline Gross Foreign Direct Investment as \% of GDP & 4.60 & 0.40 & 3.10 & 0.80 & 3.90 & 1.50 \\
Royalty and license fees payments (\$ mil) & 1938 & 306 & 19901 & 11099 & 5243 & 337 \\
Royalty and license fees receipts (\$ mil) & 110 & 83 & 42962 & 10462 & 3149 & 146 \\
Science \& engineering enrolment ratio & 43 & 25 & 19 & 21 & 47 & 50 \\
(\% of tertiary level students) & & & & & & \\
Researchers in R\&D & 742700 & 149326 & 1114100 & 675898 & 259597 & 505778 \\
Researchers in R\&D/mil. pop. & 583.88 & 157.38 & 4048.33 & 5322.03 & 3154.28 & 3492.94 \\
Total expenditure for R\&D as \% of GNP & 1.00 & 1.23 & 2.69 & 2.98 & 2.48 & 1.00 \\
Total R\&D expenditure (bill, PPP) & 60 & 19 & 253 & 97 & 48 & 12 \\
Manuf. Trade as \% of GDP & 36.79 & 12.47 & 14.98 & 13.87 & 45.23 & 18.22 \\
Scientific and technical journal articles & 11675 & 9217 & 163526 & 47826 & 37308 & 15654 \\
Scientific and technical journal articles/mil. pop. & 9.31 & 9.23 & 586.80 & 377.62 & 454.89 & 106.99 \\
Patent applications granted by the USPTO & 266 & 179 & 98666 & 34891 & 11895 & 239 \\
Patent applications granted by the USPTO/mil pop. & 0.21 & 0.17 & 345.81 & 274.67 & 144.48 & 1.65 \\
High Tech exports as \% of manuf. exports & 20.00 & 6.00 & 32.00 & 26.00 & 18.00 & 8.00 \\
\hline
\end{tabular}

SOURCE: World Bank SIMA database

Private education was gradually legalized and encouraged at various levels, and higher education was significantly expanded. As a result, from 1978-2000, adult literacy increased from 64\% to 91\% (World Bank SIMA database); from 1982-2000, the average number of years of education for the population aged fifteen and above increased from 5.33 to 7.85 , and for the total labor force, it increased from 5.81 to 7.99 . For the secondary industry, where manufacturing is the bulk, it increased from 8.05 to 9.44 (Chinese Census 1982, 2000). In addition, from 1980-2000, China's primary enrollment ratio (net) increased from $93.9 \%$ to $99.1 \%$, secondary (gross) increased from $45.9 \%$ to $68.2 \%$, and tertiary (gross) rose from $2 \%$ to $13 \%$, passing $15 \%$ in recent years (World Bank SIMA database; Chinese Educational Statistical Yearbook).

Though small scaled by the population, in absolute terms, both China and India 
have great strengths in terms of technology and innovation capacities, especially when measured by the number of researchers in $\mathrm{R} \& \mathrm{D}$, science and technical enrollment, total R\&D expenditures (PPP), and the number of scientific and technical journal articles (Table 2).

China's business sector is spending more and more on R\&D (Table 3), illustrating their enhanced capacities and increased demand for technology as well as stronger linkage between $R \& D$ and the market. Towards this end, China's "jumping into the sea" strategy was quite effective.

TABle 3. R\&D SPENDING BREAKDOWN (\%)

\begin{tabular}{l|c|c|c}
\hline & Business & GRI & University \\
\hline China (2001) & 61.2 & 28.7 & 10.1 \\
India (1998-99, roughly) & 22.0 & 75.5 & 2.5 \\
\hline
\end{tabular}

SOURCE: World Bank internal database and country statistics

Traditionally, there has been a serious mismatch between China's $R \& D$ and the production sector. Funded by an annual budget from the central or local government, public research institutes (PRIs) conducted research projects guided by five-year national plans, or other central or local plans about which industrial managers were rarely consulted. Scientific and technological knowledge was perceived as a free public good, leaving little incentive for researchers in PRIs and universities to transfer their research results to commercial applications. As a result, transfers from PRIs and universities to industry were left mostly to serendipity. To respond to these problems and force R\&D organizations to "jump into the sea," the government initiated major changes in funding and managing research organizations and technology markets. After more than a decade, the country's innovation system indeed changed. For example, government appropriations as a share of PRI income decreased by an average of 5\% each year from 1986 to 1993 . By 1993, only $28 \%$ of PRI income came from direct government appropriations, compared with 64\% in 1986. PRIs were able to generate close to $60 \%$ of their income from nongovernmental sources - half from technical services rendered to industrial enterprises. Similar changes also took place in universities (Dahlman and Aubert 2001).

\section{India}

In India, the new Congress government of June 1991, with Manmohan Singh as Finance Minister, acted quickly to carry out reforms with emphasis on deregulation and market orientation. ${ }^{1}$ The initial burst of reforms was the key to a swift revival of domestic and external confidence. Encouraged by initial success, India went forward with a series of reforms during the past few decades: opening up more sectors for private investment, encouraging FDI, significantly reducing red tape, 
further liberalizing trade policy and the exchange rate regime, and reforming capital markets, leading to an improved investment climate.

In 2000, the Indian Prime Minister laid down a vision for India's development as a knowledge society, stating that "a knowledge based society will enable us to leapfrog in finding new and innovative ways to meet the challenges of building a just and equitable social order and seek urgent solutions." Built on his vision, India's Planning Commission developed a report in 2001, identifying key drivers for the Indian knowledge society for the twenty-first century (Box 3).

\section{BOX 3. Key DRIVERS FOR THE INDIAN KNOWLEDGE SOCIETy}

The report focuses on education as the foundation for the knowledge driven economy, and examines
issues related to connectivity, governance, and use of IT to reduce the digital divide. As part
of a strategy to become a knowledge driven economy, it recommends a four-tiered approach
for increasing employment in the new economy that includes:
- creating structures for biotechnology promotion and application;
promoting knowledge-based service industries in which India has competitive strengths
(such as software and IT);
packaging and marketing traditional knowledge, especially in medicine; and
improving capacity building in three mutually supportive areas: 1) human resources
development; 2) R\&D capabilities; and 3) application of technologies flowing from innovations.

SOURCE: Indian Planning Commission 2001

Fueled by these new initiatives and reforms, India continued to make good progress in pushing economic growth and improving living standards. After growing at about $3.5 \%$ from the 1950 s to the 1970 s, India's economy expanded during the 1980 s to reach an annual growth rate of about $5.5 \%$ at the end of the period. It increased its rate of growth to $6.7 \%$ between 1992-93 and 1996-97. After a short slowdown period, growth surged to $10.4 \%$ in the third quarter of 2003-04, compared with $8.4 \%$ in the second quarter (Dahlman and Utz 2005).

During the knowledge wave, to a large extent due to deregulations and encouragement of private investment as well as other catalytic measures, the service sector emerged as the most dynamic sector in the Indian economy. The most visible and well-known dimension of the services sector takeoff has been in software and information technology (IT) based services (including call centers, design, and business process outsourcing).

Except for a productive policy environment, India's broad global Diaspora and large pool of scientists and engineers played crucial roles in tapping into global knowledge and boosting the country's high-tech industries.

\section{(1) Tapping into Global Knowledge via the Diaspora}

Similar to China, India also has a large and well-educated global Diaspora (about 
20 million in 2001). According to the US Census of 2000, the Indian Diaspora in the United States is wealthy and growing rapidly. The Indian American community now boasts 1.68 million people compared to .81 million in 1990 - a growth of $106 \%$. The average per capita income is $\$ 60,093$ (compared to a national average of $\$ 38,885$ ). Indian Americans have a very high level of education, with more than $87 \%$ of Indo- Americana having completed high school and $62 \%$ having some college education (compared to just over 20\% for the US population).Though the majority acquired their higher educational qualifications in India, particularly in engineering and IT sectors, many Indians have undertaken some study in the US institutions.

The launch of economic reforms in India in 1991 opened up new business opportunities for the Indian community in the US. These Indians have had an important role to play in high technology development in India, primarily in the software industry. Many IT professionals rely heavily on strengths back home - the huge pool of skilled computer experts and software professionals - to sub-contract work to their country of origin, thus creating several virtuous cycles for the Indian IT sector and economy. For example, in the software industry and IT-enabled services, investments of Diaspora members are quite limited (about 3\% of FDI), but their contribution is mostly in the form of knowledge linkages: with foreign markets and helping Indian firms absorb technical and managerial knowledge. Building on India's strength as a location for low-cost and quality services, the initial impetus for outsourcing to India comes mostly from employees of Indian origin (Box 4).

According to Saxenien's (2002) findings on the degree of connectedness of Indian Diaspora with their home country, $77 \%$ of the Indian born had one or more friends who returned to India to start a company; 52\% travel to India on business at least once a year; $27 \%$ report regularly exchanging information on jobs/business opportunities with those back home; and $33 \%$ report regular exchanges of information on technology.

\section{Box 4. Indian Diaspora Facilitated Outsourcing Movement}

Indian professionals, venture capitalists (VCs) and entrepreneurs of Indian origin helped promote India as an outsourcing destination, according to a study conducted for the World Bank Institute by Evalueserve Inc., a business intelligence and research firm.

By the 1990s, many Indian engineers, who started moving to the U.S. in the 1960 s, had either become entrepreneurs, VCs or senior executives in large and medium-size companies. Many of these professionals started their own companies in India, while others persuaded their companies to hire Indian IT professionals. This provided more visibility to the Indian talent pool and resulted in the strengthening of the Diaspora. For example, by late 1999, Indians constituted approximately 24 percent of the IT professional population of Silicon Valley.

Some VCs in the U.S., particularly those of Indian origin, are actively funding companies that have back-end operations in India to save on $R \& D$ costs. As of March 2004, more than 150 U.S. startups had some back-end operations in India, and the number is likely to double by 
March 2006. Because fewer funds are available to startups now than before the dot-com boom and bust, offshoring R\&D is key to the strategy of these companies. Whether the work is outsourced to India, or to any other offshore outsourcing location, can to an extent be influenced by where key employees come from.

SOURCE: Ribeiro 2004

\section{(2) High-tech Industries - New Drivers of Economic Growth}

One notable phenomenon in India is the surge of high-tech industries, characterized by thriving software and IT sectors (especially outsourcing) and emerging pharmaceutical and biotechnologies, which have become the new engines of Indian economy.

\section{(i) Booming IT Software and Service Industries}

India can boast remarkable and impressive global achievements in the IT sector. Bangalore $^{2}$ and more recently Hyderabad, Chennai, Mumbai, and Pune are emerging as competitive IT hubs in the country. Overall, the Indian IT market has grown from US\$1.73 billion in 1994-95 to US\$16.5 billion in 2002-03, accounting for $3 \%$ of India's GDP in 2002-03. The growth in the Indian IT industry has been largely driven by exports (Figure 3). IT software and services exports registered a growth of $18.4 \%$ in $2002-03$, recording revenues of US\$7.2 billion. The share of software exports in total merchandise exports grew from a negligible amount in 1990 to over $6 \%$ in 1998-99, largely due to the efforts of domestic rather than foreign firms. Top 5 firms account for $32 \%$ of exports (three have crossed US $\$ 1$ billion annual revenue), and ninety-five MNCs account for $26 \%$ exports (Bhatnagar 2004). Industrial sales and revenues have been soaring since mid-1990s (Table 4). In 2004, only the software industry accounts for $3.3 \%$ of global outsourcing market, and $2 \%$ of India's GDP.

FIgURE 3. INDIAN SOFTWARE AND IT SERVICE INDUSTRY

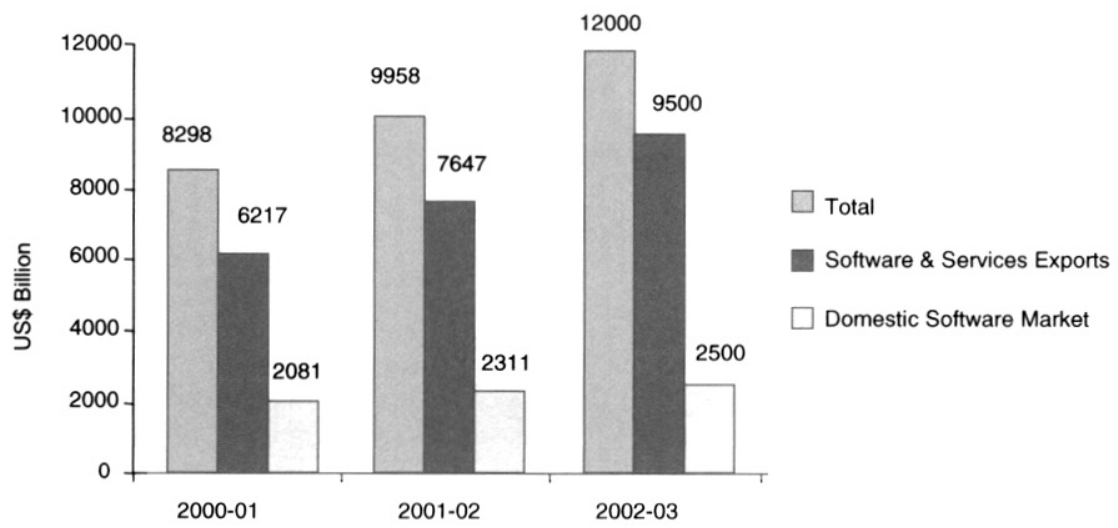


IT-enabled services or remote processing services are a hot growth market for the Indian software and services industry and is an area that is expected to generate significant employment opportunities in the future. Some of the well-known services that have substantial potential to generate wealth and create jobs include call centers and customer interaction services, business process outsourcing and back-office operations, insurance claims processing, medical transcription, legal database, digital content development, online education, data digitalization/GIS, payroll/human resource services, and web services.

TABle 4. Sales and ReVenues of Indian SOFTware Industry (US\$, Millions)

\begin{tabular}{c|c|c|c|c}
\hline Year & Exports & Domestic Sales & Total Revenues & Domestic Sales/Exports \\
\hline $1987-88$ & 52 & 74 & 126 & $142 \%$ \\
$1990-91$ & 128 & 115 & 243 & $90 \%$ \\
$1995-96$ & 735 & 487 & 1,222 & $66 \%$ \\
$2000-01$ & 6,230 & 2,173 & 8,403 & $35 \%$ \\
$2001-02$ & 7,680 & 2,420 & 10,100 & $32 \%$ \\
\hline
\end{tabular}

SOURCE: Velosoat et al. (2003)

On top of India's cheap talents, economic liberalization and the global Diaspora played critical roles in creating a successful IT industry in India. Although the Indian software industry began its current growth trajectory in 1991-92, liberalization of this sector began in 1984 when the new government of Rajiv Ghandi issued the New Computer Policy, recognizing software as an individual industry, and launched into a policy path of corporate income tax reduction for software exporters. In 1986, the government announced its Policy for Computer Software, with the main objective of promoting the country's software sector and broadening the base of computer application areas. It also began a process of simplifying procedures for setting up software units. IT companies were granted many financial incentives, such as no customs duties on capital goods imports, no excise duty, no tax on exports profits, and five year tax holidays (Bajpai and Shastri 1998).

The financial crisis of the early 90 s thrust Indian macroeconomic policy into a full liberalization track, deepening fiscal benefits awarded to software export firms and widening its scope of applicability. This growth was further enhanced by policy efforts of NASSCOM and the Software Technology Parks of India (STPI), the latter an autonomous organization set up by India's Department of Electronics (DoE). In the late nineties, the $100 \%$ export requirement was lifted and the Minimum Alternate Tax (MAT) eliminated. Both STPI and NASSCOM were heavily involved in these decisions, reflecting their success in acting as catalysts for continuous policy improvement. These policies aimed to make capital available for investment into 
more risky areas, such as software products and packages, in light of India's declining low cost advantage (Veloso 2003).

Such selective support to industry in an otherwise constraining environment, minimal bureaucratic intervention and the lack of restrictive policy implementation provided a very productive climate for the IT industry and allowed market forces to play. Meanwhile, the Indian Diaspora and gutsy entrepreneurs who made it big overseas are bringing their riches and expertise back home, fuelling growth in India's IT industry, ${ }^{3}$ a trend that started after economic liberalization. Their contribution is not just measured in terms of monetary value, but more importantly with regards to knowledge, technology know-how, networks, entrepreneurship, mentoring, and advanced management skills. In addition, they also helped India's outsourcing movement, as mentioned earlier.

Although China is also emerging as a software outsourcing destination, boosted by its strong IT sector growth, fragmentation is keeping the country's industry from grabbing a larger share of the global software-outsourcing market (Box 5).

\section{Box 5. Can China Compete With INDia in IT SERvices?}

China's IT industry has been expanding very strongly. Since 1997, annual revenues in software and IT services have risen by 42 percent a year, on average, reaching $\$ 6.8$ billion in 2003 . Moreover, the number of English-speaking graduates in the workforce - particularly crucial in software outsourcing - has doubled since 2000 , to over 24 million in 2004. But shortcomings in the structure of China's IT industry prevent it from taking full advantage of these changes. Although revenues from IT services are rising, they are barely half of India's $\$ 12.7$ billion a year. Growth is driven by domestic demand - most customers are small and midsize Chinese enterprises. Moreover, the country's nascent foreign software outsourcing business accounts for just 10 percent of the industry's total revenue, compared with around 70 percent for India.

To compete effectively in global outsourcing, China's software industry must consolidate. The top ten IT-services companies have only about a 20 percent share of the market, compared with 45 percent commanded by India's top ten. Furthermore, China has about 8,000 software service providers, and almost three-quarters of them have fewer than 50 employees. No company has emerged from this crowded pack; indeed, only 5 have more than 2,000 employees. India, on the other hand, has fewer than 3,000 software service companies. Of these, at least 15 have more than 2,000 workers, and some - including Infosys Technologies, Tata Consultancy Services, and Wipro Technologies - have garnered international recognition and a global clientele. Fragmentation exacerbates the Chinese industry's other problems, including weak process controls and product management. Chinese software-service providers will also have to manage their talent much better. Most do little to develop their employees, and very few use stock options, training programs, and other incentives to build talent. Last, most companies will have to abandon their project-based mentality and adopt a new focus on giving clients long term value.

SOURCE: De Filippo and Jun Hou, et al. (2005)

Whether measured by size, revenue, human power, quality, process or management, China's software industry still cannot compete with India's at this stage (Table 5): 
Table 5. Software Sector: China ANd India (2001)

\begin{tabular}{l|r|r}
\hline & China & India \\
\hline Software exports & $\$ 850$ million & $\$ 6,200$ million \\
\hline Domestic software sales & $\$ 4,300$ million & $\$ 2,060$ million \\
\hline Growth rate - domestic software sales & $+55 \%$ & $+31 \%$ \\
\hline Current IT professionals & 150,000 & 522,000 \\
\hline Demand for IT professionals & 350,000 & 400,000 \\
\hline IT professionals graduating each year & 50,000 & 73,218 \\
\hline No. of software firms & 6,000 & 3,000 \\
\hline
\end{tabular}

SOURCES: NASSCOM, CSIA (China Software Industry Association)

\section{(ii) Emerging Pharmaceutical and Biotech Industries}

In recent years, the success of Indian pharmaceuticals and biotech is already drawing comparisons with its IT prowess. In 2004, the Indian Pharmaceutical and Biotech industry boasts the most number of US-FDA approved manufacturing facilities outside the US and largest number of Drug Master Files filed in early 2004, giving it access to the high growth bulk drugs market (The Economist 2003).

India's outsourced chemistry and biology $\mathrm{R} \& \mathrm{D}$ market is still small, but growing rapidly. India has a large number of contract research companies in chemistry, biology, and in the new field of drug discovery services. These companies are becoming part of the global pharmaceutical, biology, and chemical R\&D network. The increase in R\&D outsourcing in the pharmaceutical and biotechnology sectors represents a significant development. The trend is here to stay and is spreading to other related businesses, including the chemical industry, agriculture, and environmental engineering (Asian Technology Information Program).

Similar to the IT sector, India's pharmaceutical and biotech industries also benefited from the country's economic liberalization and institutional support. The Indian Government had the foresight to invest in infrastructure creation for biotechnology back in 1985 through the establishment of a dedicated Central Department for Biotechnology, when the biotech wave was at best just a ripple. The Department of Biotechnology (DBT) is the nodal agency for policy, promotion of $R \& D$, international cooperation, and manufacturing activities. In the mid-1980s, DBT focused on generating trained manpower and infrastructure development. The current focus is on genomics, proteomics, transgenics, stem cell research, and product development. The government increased its budgetary allocations from just US $\$ 404$ million in 1987-88 to US\$1,138 million in 1997-98 and to - US\$2,356 million in 2002-03. The Centers of Excellence are also planning to introduce additional venture capital funds in line with its technology development fund (TDF) to promote small and medium biotech enterprises. The Government is also creating a favorable climate by improving its IPR protection. The Indian Patents (Second Amendment) Bill 
was recently cleared by Parliament, which includes twenty year patent term, emergency provisions, and commencement of $R \& D$ immediately after filing patents (India's Emerging Biotechnology Industry 2003).

In addition, the extensive Indian Diaspora is an important contributing factor. Scientists and doctors are coming back to India to join various prestigious research labs and hospital sectors. Beyond high-end pharmaceutical and biotech sectors, Diaspora doctors were also instrumental in establishing high-quality corporate hospitals. Today, the Association of American Physicians from India has about 35,000 members and is a powerful lobby group. There are about 5,000 doctors from India in other parts of the world. They have been providing help in the areas of medical education and training; paramedical training; medical practice-drugs, equipment, and hospital management; medical research and community network; and promoting medical tourism in India involving Indian Diaspora and other nationals.

One point worth noting is the different approaches of China and India regarding FDI, which led to very different results (Box 6). For many developing countries, this presents two very different models that must be measured carefully against a country's situation.

\title{
Box 6. China AND India: Different FDI Strategies
}

\begin{abstract}
Unlike China, India took inhospitable and restrictive policies against FDI at the initial stage and did not open up until after liberalization of the economy. As a result, there is a big FDI gap between China and India. Gross FDI as a share of GDP was only 0.6 percent in 2001, much lower than in China (4.9 percent). Apparently this seems a drawback, however, in reality, this close-door approach at the beginning provided the space for indigenous industry to establish itself in India, thus laying the foundation for today's strong domestic IT sector and booming outsourcing businesses. This is exactly where China shows weakness, especially in the private sector. Now India is taking many measures to attract FDIs, maybe it is the right thing at the right timing. On the other hand, China needs to take effective measures to strengthen its domestic industry.
\end{abstract}

SOURCE: Author's research

\section{(3) Creating Talented Manpower and Innovation Capacity}

As emphasized earlier, a large number of skilled workers, especially scientific and technical workers, have been the foundation of India's success in the high-tech industries. Though still low compared to China and other comparators such as Brazil and Poland, India has made considerable progress in improving its literacy rate and educational enrollment. The literacy rate for those aged seven years and older rose from $52.2 \%$ in 1991 to $65.4 \%$ in 2001; primary and secondary enrollment rates rose from $97 \%$ and $44 \%$ in 1990 to $99 \%$ and $49 \%$ in 2000 , respectively. India led China in terms of gross tertiary enrollment rates until 1999, after which China surpassed India. In 2000, India had a tertiary enrollment ratio of $10.6 \%$ (12.7\% for China). 
Indian governments have seen education as a crucial development tool. Since independence, the education policies of successive governments built on the substantial legacies of the Nehruvian period (1944-1964), targeting the core themes of plurality and secularism, with a focus on excellence on higher education and inclusiveness of all levels of education. India's curriculum historically prioritized the study of mathematics and science rather than social sciences or arts. In 1986, Rajiv Gandhi announced a new education policy, the National Policy on Education (NPE), emphasizing that change was needed to increase financial and organizational support for the education system in an effort to tackle access and quality problems. Several initiatives were since developed to counter these problems (Lall 2005; see Box 7). Meanwhile, non-formal and private education was greatly encouraged, which have expanded rapidly.

\section{Box 7. Key Initiatives Following the Nationall Policy on Education}

- Operation Blackboard (1987-8) aimed to improve the human and physical resources available in primary schools.

- Restructuring and Reorganization of Teacher Education (1987) aimed for the continuous upgrading of teachers' knowledge and competence.

- Minimum Levels of Learning (1991) laid down levels of achievement at various stages and revised textbooks.

- District Primary Education Program (DPEP) (1993) emphasized decentralized planning and management, improved teaching and learning materials, and school effectiveness.

- Movement to Educate All (2000) aimed to achieve universal primary education by 2010 through micro-planning and school-mapping exercises.

SOURCE: Lall (2005)

India's early investments in science, engineering, and technical education couples with the privatization of education helped build up a solid core of knowledge workers. Today, India has the second largest English-speaking scientific manpower pool in the world, behind only the US. It also has a growing bank of 3.5 million technical personnel. There are over 1,670 educational institutions ${ }^{4}$ including engineering colleges, technical institutes, and polytechnics that train more than 41,000 people annually. This is in addition to graduates coming out of the prestigious Indian Institute of Technology (IIT). The quality of technical training is comparable to the best in the world (Bajpai and Shastri 1998). Table 2 (in the China section) shows that India has about 149,326 researchers in R\&D, 9,217 scientific and technical journal articles in 2001-02, and ranks among the biggest global technology players, behind the US, Japan, Germany, Russia, and China. These factors combined form a strong basis for India's innovation capacity.

\section{(4) Promoting Development through Innovation Clusters}

Innovation Clusters are drivers of innovation through the adoption of technology, modern systems and practices, and play important roles in fertilizing economic 
growth. As global competition increases, local clusters are crucial for enhancing competitiveness. India features many dynamic innovation clusters covering many industries, such as IT, electronics, rice, textiles, and jewelry processing. For example, Bangalore has developed a strong innovation cluster in IT, characterized by corporate offices, venture capitalists, business startups, and university and research labs (Box 8).

\title{
Box 8. EVOlution of Bangalore as an InNovative Cluster
}

\begin{abstract}
Bangalore started as a local cluster focused on aeronautics. Slowly it expanded into IT and then into biotech. By the end of the 1990s, many multinational companies had established R\&D centers in the city. It has acquired many of the necessary ingredients to gain such status: good educational institutions, critical mass of innovative companies, an entrepreneurial culture, and the presence of venture capital.

Unlike most cases of innovative cluster-based or networked SMEs from the South, Bangalore's development as a centre for technology intensive industries with extensive SME presence is largely a result of an initial (and strategic) location decision on the part of the central government. This was followed by public sector investment in large enterprises within technology intensive sectors and in key support institutions. These government-led interventions set into motion a process whereby over a space of three decades backward linkages developed, large numbers of skilled technicians and engineers were produced, numerous SMEs producing components or acting as job working subcontractors emerged, and high technology industrial players, both local and global, opted to locate in the city. Meanwhile, many venture capitals were popped in, which was positively correlated with the growth of software exports from Bangalore.
\end{abstract}

Within this process, Bangalore's SMEs flourished in various types of relationships with larger firms and as independent producers. Network ties, based on common schooling and the experience of having previously worked together, built a basis for collaboration amongst SMEs, and between SMEs and client firms. These bonds strengthened smaller firms and enhanced their ability to technically progress as well as compete.

The evolution of Bangalore indicates that public policy has to focus on designing a set of enabling instruments that have to be implemented at the regional and local levels. Local institutions and government will have to play an increasing role in a cluster, if it is to become truly innovation-based.

SOURCES: Nadvi (1995), Bowonder (2003)

Other notable clusters include the cotton knitwear cluster in Tiruppur, and the gems and jewelry processing cluster in the Gujarat region.

\section{(5) Transforming Traditional Sectors with Innovation and Technology}

Except for India's recent achievements in the high-tech industries, its success in the agricultural and milk sectors, through production innovation and introduction of new technologies, also sets good examples of how traditional industries can be transformed through knowledge.

The Green Revolution spanned the period from 1967-68 to 1977-78, changing India from a starving nation to one of the world's leading agricultural states. The introduction of high-yielding varieties of Indian seeds after 1965 and the increased 
use of fertilizers and irrigation are known collectively as the Indian Green Revolution, which provided the production increase needed to make India self-sufficient in food grains.

In addition, the Indian "White Revolution" since late 1960s has made India the world's largest milk producer (from 17 million tons in 1950-51 to around 88 million tons in 2002-03). Such a revolution involves both institutional innovation and technological progress. Producing milk in rural areas through producer cooperatives and moving processed milk to urban demand centers became the cornerstone of government dairy development policy. This policy initiative gave a boost to dairy development and initiated the process of establishing much-needed linkages between rural producers and urban consumers. Meanwhile, technological progress in the production and processing sectors, and the growth of per capita income, also played important roles (UN Food and Agriculture Organization (UNFAO) and International Food Policy Research Institute 2003).

\section{KEY SUCCESS FACTORS (IN A NUTSHELL)}

Based on our above analyses, we find that, on one hand, China and India's successes share many common factors, but both undertook different but pragmatic development models depending on their own situations and comparative advantages. This allowed them to fully mobilize their resources and leverage their strengths. The rich development experiences and lessons of these two giant countries can shed some light for other developing countries.

\section{Common success factors for China and India}

- Clear visions and strategies from the top leadership and concerted efforts by various levels of government with a strong commitment to success.

- Linking to the global knowledge/technology stock. In China, this is mainly realized through increasing FDI amounts, while in India, this is mainly through the global Diaspora. Although China also has a big Diaspora, the main contributions were financial and took the form of FDI. While tapping into global knowledge and technology, China and India both built very competitive knowledge-intensive industries, notably manufacturing (mainly China), ICTs, and software (mainly India). China has become the major exporter of manufacturing goods worldwide. India is standing out as the global hub of software and ICT-based services. Its offshore outsourcing business has become the key driver of economic growth. The Indian software industry leads China substantially, not only in terms of revenue but also quality, skilled manpower, project management capabilities, and execution skills.

- Creation of a critical mass of innovation and human capital capabilities through fostering a significant number of scientists and engineers, attributable to the 
government's continued emphasis on social traditions valuing science and technology education.

- Transforming traditional industries with technology and innovation.In China, this took place with rice and cereal production since the 1980s; in India, wheat and maize productions as a result of the Green revolution.

- Applying innovation clusters to promote growth. In China, this mostly happens in the electronics, computer, optics, auto, textiles, and other manufacturing sectors; in India, mostly in IT, pharmaceutical, textiles, agriculture, gem and jewelry processing, etc. Such as:

China - Zhongguangcun High-tech Cluster in Beijing, Optics cluster in Wuhan, Electronic industrial cluster in Southern China, etc.;

India - Automotive parts in Hyderabad, Pharmaceuticals in Delhi and Ahmadabad, Computer software and hardware in Bangalore, Textiles in Bhiwandi, etc.

\section{Differences in the Chinese and Indian models}

China heavily depended on FDI and built up a very competitive manufacturing sector, winning the title of "world factory." While attracting FDI, China did not actively support the development of domestic private enterprises, as to prevent them from competing with the government-protected SOEs. As a result, China's private sector has been relatively weak and lacks first-class global players.

However, India relied heavily on the domestic private sector and did not open the door to FDI until the 1990s. Through the global Diaspora, India was able to acquire cutting-edge software and ICT technology and build up world-class software and ICT development and service industries, making India the main destination of global outsourcing in these areas. Companies like Infosys, Wipro, Tata Consulting Services, and Satyam are already global players. Moreover, India is trying to develop other high-tech industries, such as pharmaceutical and biotech, and begin to provide outsourcing, thanks to ICTs.

While each model has pros and cons, both countries realized the importance of complementing the current model with that of the other. Thus, China is now paying more attention to private sector development and property rights protection, while India is trying to attract more FDI through improving its investment climate.

\section{FUTURE CHALLENGES}

Although both China and India boast great success in different areas, they are also facing serious challenges in making the transition to a knowledge economy. Main challenges are identified in the following areas:

- Major improvement in investment climate. For China, this includes strengthen- 
ing the economic incentive regime, including legal system, governance, financial sector, and fair competition. In India, this includes strengthening the economy's fiscal position and financial sector, and further integrating into the global economy.

- Major overhaul of the education system, especially education quality. In addition, both countries need further development in private education beyond simply increasing education funding. For China, one daunting challenge is to provide employment and training for the massive labor force.

- Strengthening science and technology capacities, especially the diffusion system. There is a need to encourage the business sectors to undergo more $R \& D$ and technology innovation.

- Sustaining economic growth through environment friendly technology and strategy.

- Raising productivity of traditional industries, especially farming, using new techniques and innovation.

- Narrowing the huge income and regional disparities.

\section{POLICIES FOR CONTINUED SUCCESS}

In order to combat these challenges, both countries should make concerted efforts through strong partnerships between public, private, and all other stakeholders to implement a series of effective knowledge-based measures and reforms. Some general policy suggestions can be applied to both countries:

- Improve governance and government efficiency as well as the use of ICTs to increase transparency and accountability.

- Improve the quality of education, especially higher education, by reforming the curriculum and emphasizing skills required by the knowledge economy (communication skills, problem solving skills, creativity, and teamwork ability).

- Strengthen S\&T and their applications by improving the R\&D system, enhance interactions among major players, and establish an effective diffusion system.

- Spurr R\&D and technology activities of the private sector through effective policy incentives and human capacity building.

- Further leverage innovation clusters as springboards for industrial technology generation/acquisition and diffusion.

- Build a lifelong learning system through solid accreditation, certification, and qualification, and extensive use of distance learning technologies.

Other more country-specific policy measures:

China:

- Improve the overall investment climate by establishing a well-functioning 
rule of law, improving governance, strengthening the financial sector through restructuring state-owned banks, and enhanced monitoring and supervision of the whole sector.

- Restructure SOEs through deeper corporate governance reform and an efficiency-driven approach.

- Create more employment opportunities by developing the service sectors, SMEs, and private sector, as well as provide training for the unemployed.

- Promote the private sector through further property rights protection and level playing field.

- Take more effective measures to spur technology spillovers from FDI, not just foreign capital.

\section{India:}

- Improve the investment climate by easing restrictions on hiring and firing workers, improve SMEs' access to credit, update bankruptcy procedures, reduce tariff and non-tariff barriers, and strengthen power and transportation infrastructure.

- Encourage FDI by phasing out remaining FDI restrictions and increase positive linkages with the rest of the economy.

- Stimulate growth of not only manufacturing but also service exports beyond IT sectors.

- Spur further growth of the IT and biotechnology sectors, which can stimulate the development of other knowledge-based industries.

Through these efforts and reforms, which build on current strengths in the macroeconomic environment, human capital, technology innovation, and ICTs, combined with strong growth momentum, both countries are poised to make even greater success in the future and truly become global players in the twenty-first century.

\section{REFERENCES}

Angresano, J. et al. 2002. China's Rapid Transformation: the Role of FDI. http://www.aucegypt.edu/academic/econ/FDI_PAPER.HTM.

Asian Technology Information Program (ATIP). 2003. http://www.atiorg/public/atireports.03/atip03.053.pdf.

Bowonder. B. 2003. S\&T in Bangalore. College of India, Hyderabad, India, and Asian Technology Information Program (ATIP), May 9, 2003. bttp://www.atiorg/publiclatireports.03/atip03.029.pdf.

Bajpai, N. and V. Shastri. 1998. Software Industry in India: A Case Study. Harvard Institute for International Development, Harvard University. Cambridge: MA. 
December.

Bhatnagar, Subhash. 2004. Understanding the "How" of Growth in India's Software Industry. presentation at the World Bank PREM lecture series. June.

Chen, Chunlai. 1997. The Evolution and Main Features of China's Foreign Direct Investment Policies. Working Paper of the Chinese Economies Research Center, Adelaide University.

China, China Daily. 2002. Pudong Lures Big Money. 17 June.

China, China State Statistical Bureau. 1991, 1994, 1996. China Foreign Economic Statistical Yearbook, Department of Trade and External Economic Relations Statistics. Beijing, China. - 1979-1991. China Foreign Economic Statistics. - 1982, 2000. Chinese Census. China Statistic Press.

China, Ministry of Education. Various years. Chinese Educational Statistical Yearbook. Beijing, China.

China, Ministry of Science \& Technology. 2001. China's Key Technologies R\&D Program. bttp://www.china.org.cn/baodaolenglish/newsandreport/2001july/new13-1.htm China, People's Daily. 2004. Father of hybrid rice on efforts to improve food security. 5 March.

De Filippo, Giuseppe, Jun Hou, et al. 2005. Can China Compete In IT Services? The McKinsey Quarterly, No. 1.

Huang, Yasheng and T. Khanna. 2003. Can India Overtake China? Foreign Policy, July-August Issue.

India, 2003. India's Emerging Biotechnology Industry. bttp://policy.biotec.or.th/page/biotech\%20status/biotech\%20of\%20\%20INDIA\%202003.pdf

India, Planning Commission. 2001. India as Knowledge Superpower: Strategy for Transformation. June.

Bradsher, Keith. 2005. China Looms as the World's Next Leading Auto Exporter. NY Times, June 28, 2005.

Lall, Marie. 2005. The Challenges for India's Education System. Chatham House. April. Law, Forrest. 2004. China's Developer of Super Hybrid Rice Receives World Food Prize. Delta Farm Press, 22 December 22.

Nadvi, Khalid. 1995. Industrial Clusters and Networks: Case Studies of SME Growth and Innovation. UNIDO.

Nathan, Andrew J., 1990. China's Crisis. New York: Columbia University Press. Ribeiro, John. 2004. Study: Indian Diaspora Helped Outsourcing Movement. IDG News Service, Bangalore Bureau, 4 October.

Saxenian, Annalee. 2002. Local and Global Networks of Immigrant Professionals in Silicon Valley. Public Policy Institute of California. 2002.

The Economist Intelligence Unit. 2002. CHINA HAND. London: Economist Intelligence Unit, April.

The Economist. 2003. Patently Ambitious. 4 September.

UN Food and Agriculture Organization (UNFAO) and International Food Policy 
Research Institute. 2003. Policy, Technical, and Environmental Determinants and Implications of the Scaling-Up of Livestock Production in Four Fast-Growing Developing Countries: A Synthesis. July. New York, NY.

UNCTAD, World Investment Report, United Nations, 2002. New York, NY. Veloso, F., at el. 2003. Slicing the Knowledge-based Economy in Brazil, China and India: A Tale of Three Software Industries. September.

Website of Zhongguancun Technology Park. http://www.zhongguancun.com.cn/en/ default.asp.htm

World Bank. 2001. China and the Knowledge Economy: Seizing the 21st Century. Washington, D.C.

. 2003. China - Promoting Growth with Equity (CEM), East Asia and Pacific

Region. September.

.2005a. India and the Knowledge Economy: Leveraging Strengths and Opportunities.

Washington, D.C.

. 2005b. World Bank SIMA database. Washington, D.C.

Zhang, W. 2000. Why is Foreign Investment in China Concentrated in the Coastal Areas?. Harvard Asia Quarterly, summer.

\section{ENDNOTES}

${ }^{1}$ These include rupee devaluation by 20\%; replacing the complex import licensing by a system (EXIMSCRIPS) of tradable, import entitlements earned through exports (later replaced by a dual, and then market-determined exchange rate); phased reduction of customs duties; fiscal deficit cut by $2 \%$ of GDP; foreign investment opening up; banking reforms launched; capital market reforms initiated; initial disinvestment of public enterprises announced; and major tax reforms outlined.

2 For more information, see the official website of the Department of IT and Biotechnology, Government of Karnataka http://www.bangaloreit.com/

3 By 1998, there were an estimated 774 hirtech firms in Silicon Valley led by an Indian CEO.

${ }^{4}$ Many world-class institutions of higher learning include Indian Institute of Technology (IITs), Indian Institutes of Management (IIMs), and Indian Institute of Science (IISs), etc. 